\title{
IAMJ
}

INTERNATIONAL

AYURVEDIC

MEDICAL JOURNAL

ISSN: 2320-5091

Impact Factor: 6.719

\section{MARMA CHIKITSA - A CLINICO ANATOMICAL APPROACH FOR PROMOTION OF HEALTH}

\author{
Arvind Kumar Yadav', Rita Marwaha ${ }^{2}$, Swatantra Kumar Chourasia ${ }^{3}$, Shradhha Sharma ${ }^{4}$ \\ ${ }^{1}$ PG Scholar, ${ }^{2}$ Professor, Head \& Co-guide ${ }^{3}$ Assistant Professor \& Guide, ${ }^{4}$ Assistant Professor \& Co-guide \\ ${ }^{1,2,3}$ P.G. Dept. of Rachna Sharir, PT. Khushilal Sharma Govt. Auto. Ayurved College \& Institute Bhopal (M.P.), \\ India \\ ${ }^{4}$ P.G. Dept. of Kaya-chikitsa, PT. Khushilal Sharma Govt. Auto. Ayurved College \& Institute Bhopal (M.P.), \\ India
}

Corresponding Author: yadav.drarvind4@gmail.com

https://doi.org/10.46607/iamj1609052021

(Published Online: May 2021)

Open Access

(C) International Ayurvedic Medical Journal, India 2021

Article Received: 22/04/2021 - Peer Reviewed: 04/05/2021 - Accepted for Publication: 05/05/2021

Check for updates

\section{ABSTRACT}

Marma Chikitsa is an untouched chapter of Indian system. In Vedas and literatures of ayurveda, the concept of marma was limited to war, and were mainly considered as only fatal points. Trauma to them leads to deformity or even death. Different authorities of ayurveda mentioned 107 Marma points based on anatomical positions and different structures around them. Marma are seats of Prana (Vital points), they effect physical, mental, social, spiritual and health conditions of human beings. The flow of Prana or vital energy in the body maintains different physiological, mental and spiritual activities. If the flow of Prana or vital energy gets obstructed or blocked, the physiology is disturbed and pathology start developing. Marma points are stimulated by different techniques or methods, so by stimulations, Marma may be directed to remove blockages and stimulate Prana or energy flow thus resulting in a state of healthy body, mind and spirit. Marma Chikitsa is an instant, permanent, natural and non-invasive way of healing in present scenario. Marma Chikitsa had emerged as new dimensions in nonpharmacological treatment of Ayurveda. The health of the people reflects the social welfare parameters of any 
civilized state. So, knowledge of Marma and Marma Chikitsa will be beneficial in maintenance of health and prevention from diseases.

It is said that there was nectar in the umbilicus of Ravana. Lord Rama fired an arrow into the umbilicus of Ravana causing his death. Lord Krishna was killed by the injury of an arrow, on the sole of his foot, thrown by a bird killer. As we know that Bhisma Pitamaha (of Mahabharata) was injured by a number of arrows pierced in his body but he lived with arrows for six months. It was only due to the safety of the vital Marma points.

\section{Keywords: Marma, Marma Chikitsa, Prana}

\section{INTRODUCTION}

Different Ayurved classics have dedicated a separate "Sthan" (a groups of chapters related to same topic) for the literature of Sharir Rachna. It is called "Sharir Sthan". While describing Sharir Rachna different Acharya has described about Marma or vital regions of the body. The concept of Marma is one such imperative and unique principle of Ayurved. Marma Vijyaniyam was developed as science of war. Knowledge of Marma exists from ancient period of Vedas, which dates back 4000BC. Marma has been described in all three-great treatise- Charak Samhita, Sushrut Samhita And Ashtang. The word "Marma" comes from Sanskrit origin "Mra" means place of Prana (life). Any direct or indirect trauma to these sites may be fatal or can result in disability of the person. These Marmas point harmonize the nervous and endocrine system and normalize different pathology in the body through vital power itself, with proper stimulations/Manipulation. This technique is known as Marma Chikitsa.

Marma Chikitsa is an ancient Indian practice whose purpose is stimulations / manipulation of Prana (vital energy) in the body for enhancing the healing process. Marma Chikitsa is based on the action of 107 Marmas points in the body to access the body and mind. Marma's knowledge helps the clinicians to regulate the flow of Prana through the coarse and subtle bodies in order to restore the patient's health and serenity.

Marma Chikitsa is the oldest treasure of Indian surgery from the Vedic period. During the Vedic era the knowledge of Marma was known to the emperors and warriors. The concept and practice of Marma was very popular in those days to achieve the maximum effect when contending with the enemies. ${ }^{1}$

Distribution and Description of Marma Points in the Human Body-

According to Maharsi Susruta there are 107 Marmas in the human body ${ }^{2}$. These are very important vital places. Any injury to these parts may lead to severe pain, disability, loss of function, loss of sensation (anesthesia) and death. According to anatomical consideration Marmas can be divided into Mansa-Marma, Siramarma, Snayu-Marma, Sandhi-Marma, and AsthiMarma $^{3}$ (respectively, Marma of muscle, blood vessel, ligament, joint and bone). On the basis of properties, they can be categorized into Saumya, Vayavya, Agneya and Saumyagneya Marmas ${ }^{4}$. According to site, Marmas are situated at Udara (thorax and abdomen), Prishta (back), Shakha (extremities) and Urdhvajatru (neck and head) region.

There are eleven Marma points in one leg. The same number is present in the other leg. So, these are a total of forty-four Marma points including both the upper and lower extremities. There are twelve Marma points in the thorax and abdomen. Fourteen Marma points are present in the back. Thirty-seven Marma points are located above the clavicular region (neck and head). ${ }^{5}$

\section{Fundamentals of Marma Science and Therapy-}

The human being is a finite creature in an infinite cosmos. According to Vedanta principle the absolute cosmos is conceptually limitless. It can be marked as infinite-eternal, eternal-infinite and cannot be assessed in external and absolute. In fact, as per the quotation 'Yat Pinde Tat Brahmande' all properties of the absolute cosmos are inherent in this human body. One as- 
pect of these inherent powers of self-healing is demonstrated by our Rishis as Marma Science.

Basically, Ayurveda strives to keep the body healthy and prevent illness. Illness is the condition when the body gets tired excessively or weak and this condition affects the normal physiological functions of the body. A number of suitable measures are advocated in Ayurveda to prevent the illness and to keep the body healthy and fit. ${ }^{6}$

Marma Chikitsa - Marma Chikitsa is very popular in many places as a traditional skill. A number of bonesetters and Nadi Vaidyas practice by this specialty. But as a traditional skill it has no scientific explanation behind it, and it is limited to some traumatic lesions of muscles and bones. The scientific presentation of Marma therapy is the need of the hour. This science is still obscure. In the light of theoretical description available in the old texts and present research and knowledge, Marma Chikitsa has been further developed and practiced. ${ }^{7}$

Marma therapy contributes to increase or recharge physical, mental and spiritual energies. On the physical level it helps to revitalize or reenergize the body tissues; at cellular level, it improves the vital functions like digestion, respiration, blood circulation and excretion. On the psychological level it improves the mental faculty by directing it in the positive direction. ${ }^{8}$

\section{Marma Chikitsa in Different Diseases'-}

Marma Chikitsa can be used in the following ways-

- To treat the diseases of nerves and brain.

- In traumatic neurological or neuro surgical lesions, traumatic paraplegia, hemiplegia and monoplegia.

- In orthopaedic lesions, especially prolapsed inter vertebral disc etc.

- To reduce the pain of nerves, muscles, ligaments, bones and joints.

- To produce anesthesia during any surgical interference.

- To improve the function of body organs by achieving homeostasis.

- To activate the mal-developed or deformed body parts or musculature etc.
- To prevent and treat the lifestyle disorder. ex,diabetes, hypertension, thyroid disorder etc.

Following Marma points are responsible for the relief of pain in different organs. ${ }^{10,11,12}$

$>$ Shoulder pain - Kshipra Marma and Kurpara Marma.

$>$ Pain in abdomen - Kurpara and Urvi Marma.

$>$ Chest Pain - Kurpara, Urvi and Ani.

$>$ Cervical (neck) pain - Kshipra, Kurpara, and Ani Marma

$>$ Leg and knee pain - Kshipra, Gulpha

$>$ Sciatic pain - Kshipra, Gulpha

$>$ Cerebral palsy - upper and lower extremities Maramas

> Torticolitis and cervical spondylosis- upper and lower extremities Maramas, Dhamni, Matrika, Krikatika, Amsa and Amsaphalaka Marma etc.

Different Procedures / Methods in Marma ChikitsaExamination of the body surface for the assessment for locating the proper Marma point is necessary. Actually, it is impossible to give the exact location because of individual differences. Before Marma therapy one has to determine the actual location of specific Marma points. The exact location of Marma varies according to an individual according to the measurement of the body and body parts. The site is described in relation to the bony prominences, joints and other body structures. The distance is described in finger measurement of the individual. The extent of each type of Marma is also discussed. The location of Marma points is described in the text Susruta Samhita extensively. The size of the particular Marma is also mentioned. ${ }^{13}$

\section{Procedure-}

Posture- Sukhasana, Padmasana, Vajrasana

Pressure- According to nature of MARMA

Stimulation time- $0.8 \mathrm{sec} . /$ stimulation

Repetition- 15-18 times in single seating

Time- three times in a day

Other methods of MARMA stimulation ${ }^{14}$ -

$\checkmark$ Rubbing

$\checkmark$ Itching

$\checkmark$ Vibration

$\checkmark$ Oil massage 
$\checkmark \quad$ Paste application

$\checkmark$ Fomentation

The most common postures for the practice of selfMARMA Chikitsa are - Simple cross-legged posture (Sukhasana)

2. Lotus posture (Padmasana)

3. Half lotus posture (Ardha Padmasana)

4. Diamond posture (Vajrasana)

5. Sitting posture on chair

6. Standing posture

Examination of the body surface for the assessment for locating the proper Marma point is necessary. Actually, it is impossible to give the exact location because of individual differences. Before Marma Chikitsa one has to determine the actual location of specific Marma points. The exact location of Marma varies according to an individual according to the measurement of the body and body parts. The site is described in relation to the bony prominences, joints and other body structures. The distance is described in finger measurement of the individual. The extent of each type of Marma is also discussed. The location of Marma points is described in the text Susruta Samhita extensively. The size of the particular Marma is also mentioned.

Pre therapy exercises: - It comprises of the following steps: -

$>$ Total relaxation of body.

$>$ Deep breathing exercise.

$>$ Perception of body as whole.

$>$ Perception of psychic centers.

$>$ Perception of Marma points.

$>$ Gentle massage with thumb and fingers over the Marma points.

Then comes the actual Chikitsa consisting of application of pressure with thumb or fingers over the Marma points.

\section{Health Promotion by Marma Therapy and Yogic Practices-}

Man is the best creature of God. The human body is made up of the five basic elements and soul. In spite of this quality the human body is the subject of all activities (Dharma Artha Kama and Moksha).
In Charaka Samhita this Sada Dhatu Purusa is known as Cikitsya Purusa ${ }^{15}$. The human body is constituted by different systems: all these systems work together regularly without any hindrance. The human body is made up of seven basic Dhatus i.e. Rasa, Rakta, Mansa, Meda, Asthi, Majja and Sukra. A number of changes occur in the human body during the whole life span, the homeostasis of Doshas is known as health; imbalance in the DOSHIC state may lead to the disease ${ }^{16}$ : Shariram Vyadhi Mandira means the body is the seat of diseases.

The aim of Ayurveda is to preserve the health of a healthy individual and to cure the diseases of a diseased person ${ }^{17}$. There is a major role of Marma Chikitsa and Yoga along with Ayurveda to fulfill the above-mentioned goal. The whole world is requiring Marma therapy and YOGA as a weapon to combat the diseases of modern life. Marma Chikitsa and yoga is practiced by many people for achieving the healthy state of life. A number of incurable diseases are treated with Marma Chikitsa and Yogic practices.

In the present era we suffer from a number of ailments. The main cause of such sufferings is stress generated by competitiveness, changing lifestyle and behavior. As a result, the human being suffers from physical and mental illness. Adhyatmic, Adhibhautik, and Adhidaivik are three types of sufferings; these sufferings can be treated with Mantras, Marma therapy and Yoga and Ayurveda collectively.

\section{DISCUSSION}

The marma point harmonize the nervous and endocrine system and normalize different pathology in the body through vital power itself, with proper stimulation, manipulation. These techniques are known as Marma Chikitsa.

According to Acharya Sushruta, the point where all the vessels, muscles, bones, joints, nerves, ligaments etc. structures meet and is the site of Prana (vitality) is nothing but Marma. ${ }^{18}$ Acharya Vaghbhata considered Marma as the points where special and unusual pulsation felt. These points are important in human body and injuries to these points lead disability and if not treated properly may become fatal. ${ }^{19}$ 
Marma Chikitsa contributes to increase vital power and this vital power work in positive direction for maintaining health.

Marma Chikitsa activates our nervous system, when nervous system activates then neurotransmitter, hormones, prostaglandin etc., work in proper manner, therefore Marma Chikitsa commonly used it treat nerves and brain (traumatic, neurological or neurosurgical lesions ex-traumatic paraplegia, hemiplegia and monoplegia.). It is used in both upper motor neurons lesion and lower motor neurons lesion, systemic diseases of spinal cord (orthopedic lesion specifically prolapsed inter vertebral disc etc.). it is also used to reduce the pain of nerves, muscles, ligaments, bones and joints as Marma Chikitsa work by the reducing the recreation of prostaglandins. Therefore, Marma Chikitsa act as inhibitor for prostaglandin secretion. (ex.- Amsaphalak Marma used the treatment of shoulder joint pain).

It is used to improve the functions of body organs by achieving homeostasis. It is used to prevent and treat the lifestyle disorder like - diabetes, hypertension, thyroid disorder etc.

Marmas points also made up of Tridosh and Panchmahabhuta, in Marma Chikitsa is a non-invasive technique for balancing the Doshas and Dhatus. Marma points also site for Bhutatma so by the Marma Chikitsa also maintain the equilibrium of mental state of human body. Thus, the Marma Chikitsa is helpful in the prevention and cure the diseases by the balancing of Sharirik and Manshik Doshas.

Marma Chikitsa are related to Shatcakra also, because Shatchakra are also site of different Marma points, and Shatchakra activates Marma points and they work in physical and mental disorders by the maintain the harmony of body.

\section{CONCLUSION}

Marmas are vital points, centers for the Prana. They can be used specifically for the diagnosis and treatment of disease or generally for promoting health and longevity. Marmas are integral to all Ayurvedic therapies from simple self-treatments to complex clinical procedures. They form one of the main pillars of
Ayurvedic thought and practice. Marma therapy can be used along with all Ayurvedic Chikitsa like Panchakarma.

Marma Chikitsa is the best technique to attain the effects of Yoga and Pranayama.

To advance understanding and treatment of diseases through prevention, education and research, Marma Chikitsa, and Yoga can offer an effective way of healing.

\section{REFERENCES}

1. Dr. Sunil Kumar Joshi. Marma Science and Principles of Marma Therapy, New Delhi, Vani Publications, 2019 page-33

2. Ghanekar Dr. Bhaskar Govind. Ayurveda Rahusya Deepika Hindi commentary on Sushruta Samhita sharir Sthanam. New Delhi, Mehar Chand Lachmandas Publication 1998. Su. Sharir 6/2 page 183

3. Ghanekar Dr. Bhaskar Govind. Ayurveda Rahusya Deepika Hindi commentary on Sushruta Samhita sharirSthanam. New Delhi, Mehar Chand Lachmandas Publication 1998. Su. Sharir 6/2 page 183

4. Shastri Dr. Ambika Dutta. Sushrut Samhita, Ayurved Tattva Sanddipika Varanasi, Chaukhamba Sanskrit sansthan Varanasi, 2012. Su. Sharir 6/17 page-70

5. Ghanekar Dr. Bhaskar Govind. Ayurveda Rahusya Deepika Hindi commentary on Sushruta Samhita sharir Sthanam. New Delhi, Mehar Chand Lachmandas Publication 1998. Su. Sharir 6/4 page 184

6. Dr. Sunil Kumar Joshi. Marma Science and Principles of Marma Therapy, New Delhi, Vani Publications, 2019 page-33

7. Prof. Dr. Sunil Kumar Joshi. Marma Chikitsa vigyanan Science, New Delhi, Vani Publications, 2019 page- 47

8. Dr. Sunil Kumar Joshi. Marma Science and Principles of Marma Therapy, New Delhi, Vani Publications, 2019 page-40

9. Dr. Sunil Kumar Joshi. Marma Science and Principles of Marma Therapy, New Delhi, Vani Publications, 2019 page- $42-50$

10. Dr. Sunil Kumar Joshi. Marma Science and Principles of Marma Therapy, New Delhi, Vani Publications, 2019 page-55

11. Negi Vinita kumara, Parvat susheela, Vyas anju Sharma om \& Sharma S.K. "Marma and marma therapy:A review", Reviw article WJPR, volume7 issue 15, 258-271 date 15 july 2018 
12. Gaurav rajendra sawarkar, punam gaurav sawarkar, "APPRAISAL OF OLEATION THERAPY WITH RESPECT TO INDIAN MEDICINE MARAMA POINTS" Reviw article ujahm 2017, 05(03): page-1823

13. Dr. Sunil Kumar Joshi. Marma Science and Principles of Marma Therapy, New Delhi, Vani Publications, 2019 page-59

14. Negi Vinita kumara, Parvat susheela, Vyas anju Sharma om \& Sharma S.K. "Marma and marma therapy: A review", Reviw article WJPR, volume7 issue 15, 258-271 date 15 July 2018 page -266 and Dr. Sunil Kumar Joshi. Marma Science and Principles of Marma Therapy, New Delhi, Vani Publications, 2019 page-5970

15. Shastri Kashi Nath, Vidyotini Commentary on Charka Samhita, Varanashi: Chaukhamba Bharti Academy, 2018. Ch. Sharir $1 / 16$ page -801

16. Kaviraj atridev gupt, Vidyotini Commentary on Astang hridaya, Varanashi: Chaukhamba Bharti Academy, 2018. Astang hridaya sutra $1 / 20$ page -12

17. Shastri Kashi Nath, Vidyotini Commentary on Charka Samhita, Varanashi: Chaukhamba Bharti Academy, 2018. Ch. Sutra $30 / 26$ page -587

18. Shastri Dr. Ambika Dutta. Sushrut Samhita, Ayurved Tattva Sanddipika Varanasi, Chaukhamba Sanskrit sansthan Varanasi, 2012. Su. Sharir 6/16 page-69

19. Ghanekar Dr. Bhaskar Govind. Ayurveda Rahusya Deepika Hindi commentary on Sushruta Samhita sharirSthanam. New Delhi, Mehar Chand Lachmandas Publication 1998. Su. Sharir 6/2 page 183

\section{Source of Support: Nil}

\section{Conflict of Interest: None Declared}

How to cite this URL: Arvind Kumar Yadav et al: Marma Chikitsa - A Clinico Anatomical Approach For Promotion Of Health. International Ayurvedic Medical Journal \{online\} 2021 \{cited $\quad$ May, 2021$\}$ Available from: http://www.iamj.in/posts/images/upload/1044 1049.pdf 